\title{
Measuring Regulating Ecosystem Services for the Impacts of Global Climate Change and Air Quality Service in Wageningen Case Area
}

\author{
Betül Tülek ${ }^{1,2}$
}

\author{
${ }^{1}$ Environmental Systems Analysis Group, Wageningen University, Wageningen 6708 PB, The Netherlands \\ Email: betul.tulek@wur.nl \\ ${ }^{2}$ Çankırı Karatekin University, Faculty of Forestry, Department of Landscape Architecture, 18200, Çankırı, Turkey \\ Email: betultulek@karatekin.edu.tr
}

Received: 30 Nov 2021; Received in revised form: 19 Jan 2022; Accepted: 02 Feb 2022; Available online: 08 Feb 2022 (C)2022 The Author(s). Published by Infogain Publication. This is an open access article under the CC BY license (https://creativecommons.org/licenses/by/4.0/).

\begin{abstract}
Wageningen is a city of some 38.000 people and is located in the province of Gelderland on the North bank of the Lower Rhine. In this research, Lower Rhine river and around which covers $75.16 \mathrm{~km}^{2}$ within the boundaries of Wageningen city, has chosen as a research area. The aim of this research is to evaluate the contribution of the vegetation canopy formed by trees and tall shrubs to the regulating ecosystem services in terms of improving the air quality and the economic estimation of these contributions in research area. I-tree canopy v7.1 tool was used to perform to analyse within the scope of the research. 8 land cover types and their distributions were identified in the area and a total of 3000 points were randomly assigned for each class. As a result of the research, it has been estimated that the vegetation covering $16.03 \%$ of the research area removes a total of 103.34 tons of pollutant gas and particles from the air, the carbon amount captured by the tree canopy annually is 13.490 tons, and the total carbon stored by the tree canopy is estimated as 338.840 tons. In this context, increasing the amount and quality of open-green areas in the selected region, protecting trees and tall shrubs and increasing their diversity, ecosystem services provided from these areas will also increase and contribute to the city economy in the future.
\end{abstract}

Keywords - Air quality, i-Tree canopy, Regulating ecosystem services, Wageningen, the Netherlands

\section{INTRODUCTION}

The concept of ecosystem services was first used in the literature by Ehrlich and Ehrlich in 1981, based on [1] term "Natural Services". The most accepted definition of the ecosystem services concept was stated in the Millennium Ecosystem Assessment (MEA) report published in 2005 as 'benefits that people derive from ecosystems' [2,3,4]. Ecosystem services are handled in 4 main categories as providing, regulating, supporting and cultural services [2].

Regulating ecosystem services are benefits derived from natural processes controlled by ecosystems. Improvement of air and soil quality, climate regulation, mitigation of natural disasters such as floods and landslides, disease control, water filtration, waste management, pollination, biodegradation or control of harmful species can be listed as regulating services [2].

Outdoor air quality are important to human health. The average $70 \mathrm{~kg}$ adult inhales about $20 \mathrm{~m}^{3}$ of air per day [5]. Pollutants that cause outside air pollution are found in the atmosphere in the form of gas (C-carbon, $\mathrm{NO}_{2}$-nitrogen dioxide, O-ozone, $\mathrm{SO}_{2}$-sulfur dioxide) or particles (PM particle matter) [6]. Many groups of patients such as asthmatics, atopic patients, patients with emphysema and bronchitis, heart and stroke patients, diabetes, pregnant women, the elderly and children as especially sensitive to the health effects of outdoor air toxicants [7]. 
$\mathrm{CO}_{2}$ has a significant effect on the increase in air temperature by creating a greenhouse effect in the atmosphere, and the increase in air temperature causes long-term climate change, negatively affecting plants and agriculture. The increase in the concentration of $\mathrm{O}_{3}$, which is one of the greenhouse gases, in the atmosphere causes respiratory and heart diseases in humans, and the closure of the respiratory pores in plants disrupts the photosynthesis mechanism, causing less carbon dioxide absorption and a slowdown in growth rate [8].

Measuring ecosystem services and air quality by using mathematical methods are very important in recent years [9]. I-tree canopy model used in this research is a tool that gives rapid results and is used in the calculation of regulating ecosystem services for improving air quality, which is a factor that significantly affects climate change, based on tree canopy. The results obtained from the model clearly reveal the data on the benefits of the trees and tall shrubs forming the canopy to the ecosystem [10].

In this study, it was aimed to determine the regulating ecosystem services for improving the air quality provided by the tree canopy available within the boundaries of the Lower Rhine region research area, where city, nature and culture coexist in the city of Wageningen and which is under the influence of intense recreational uses.

\section{MATERIAL AND METHOD}

Lower Rhine river and around is chosen as a research area in Wageningen city, which covers $75.16 \mathrm{~km}^{2}$ (Fig. 1)

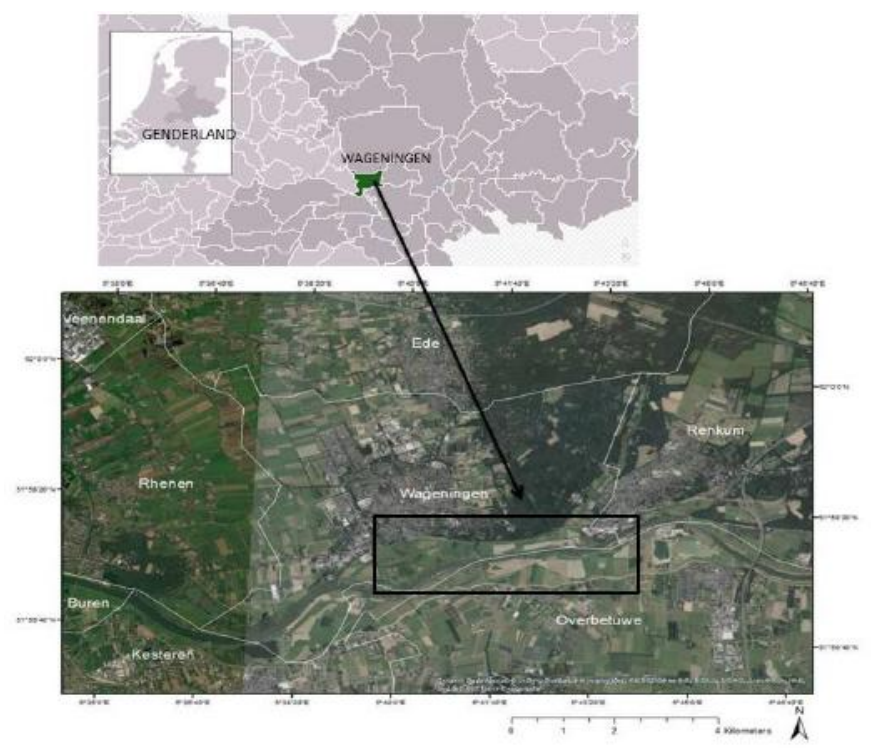

Fig. 1: Location of research area [11]

Wageningen, Renktum, Randwijk, Zetten, Opheusden, Kesteren are urban landscapes; Historical Brick Factory,
Ironworks Ruins, Outbuildings are as historical and touristic landscapes, located in the research area (Fig. 2).

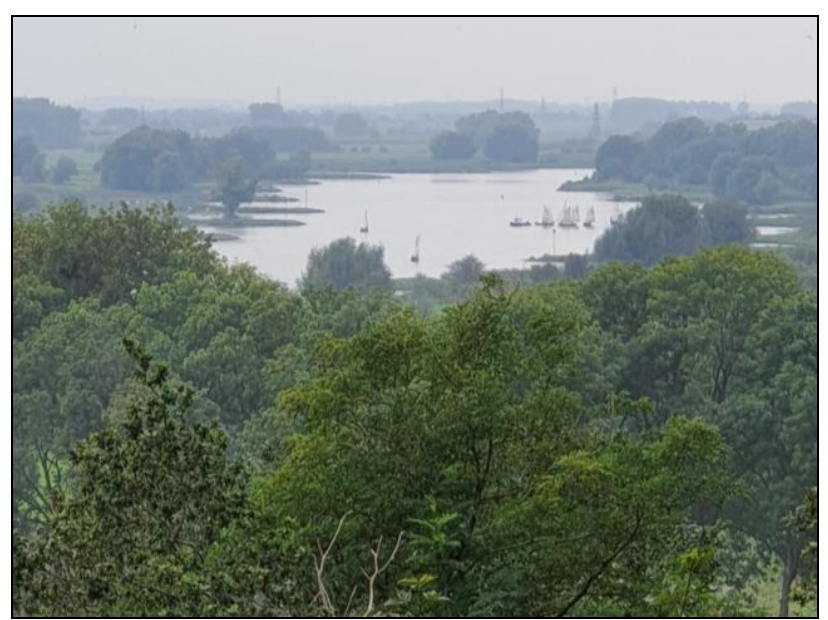

Fig. 2: A view of the research area (Original, 2021)

Within the scope of the research, I-tree canopy tool, which was developed by the Forest Service unit of the United States Department of Agriculture, was used to analyze the tree cover and to calculate the regulating ecosystem services provided by the tree canopy for the improvement of air quality. i-Tree Canopy v7.1 is a free web-based application tool that uses random point sampling and works in conjunction with Google MapsTM satellite imagery [12].

To calculate the tree cover and the monetary value for the research area, the free online tool i-Tree Canopy Version 7.1 in 2021 was also used. The boundary of research area ESRI shape files were imported into the i-Tree Canopy tool. A total of 3000 random points were interpreted for the research area.

8 land cover classes (Agricultural areas, Grass/Herbaceous, Impervious Buildings, Impervious Roads, Impervious Other, Soil/Bare Ground, Tree/Shrub, Waters) identified in research area and a total of 3.000 points were randomly assigned for each class (Fig. 3).

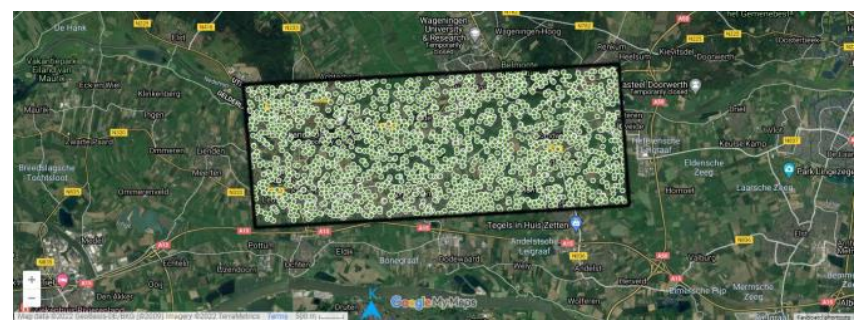

Fig. 3: Distribution of sampling points in the area

After the classes corresponding to the points were defined, the results were taken as a report on the same module. 


\section{RESULTS AND DISCUSSION}

\subsection{Land Cover Types of Research Area}

8 different land cover classes determined as a result of the study carried out in the $75,16 \mathrm{~km}^{2}$ research area, the number of sample points for each class, the area covered by each class in the district $(\%)$ and standard error rates (\%) are given below (Table 1$)$.

Table 1: Land cover types analysis with i-Tree canopy tool in the area

\begin{tabular}{|c|l|c|c|}
\hline $\begin{array}{r}\mathbf{N} \\
\mathbf{o}\end{array}$ & Land cover types & $\begin{array}{c}\text { Number } \\
\text { of points }\end{array}$ & \% Cover \pm SE \\
\hline $\mathbf{1}$ & Agricultural areas & 1254 & $41.80 \pm 0.90$ \\
\hline $\mathbf{2}$ & Grass/Herbaceous & 434 & $14.47 \pm 0.64$ \\
\hline $\mathbf{3}$ & Impervious Buildings & 195 & $6.50 \pm 0.45$ \\
\hline $\mathbf{4}$ & Impervious Other & 71 & $2.37 \pm 0.28$ \\
\hline $\mathbf{5}$ & Impervious Roads & 205 & $6.83 \pm 0.46$ \\
\hline $\mathbf{6}$ & Soil/Bare Ground & 100 & $3.33 \pm 0.33$ \\
\hline $\mathbf{7}$ & Tree/Shrub & 481 & $16.03 \pm 0.67$ \\
\hline $\mathbf{8}$ & Waters & 260 & $8.67 \pm 0.51$ \\
\hline & Total & 3000 & 100.00 \\
\hline
\end{tabular}

$31.35 \mathrm{~km}^{2}$ of which constitutes $41.8 \%$ of the research area is followed by agricultural areas, followed by forest areas consisting of trees and shrub vegetation with $12.03 \mathrm{~km}^{2}$. The least common land cover types in the study area are other impervious surfaces $\left(1.78 \mathrm{~km}^{2}\right)$, soil/bare areas $(2.5$ $\mathrm{km}^{2}$ ) and impervious buildings $\left(4.88 \mathrm{~km}^{2}\right)$.

The pollutants removed from the atmosphere and the carbon capture and storage amounts in one year by means of tree cover measurement in the research area with the iTree tool are given in Table 2. With a general evaluation, it was found that the tree cover removed a total of 103.34 tons of pollutant gases and particles from the air in the study area in one year. Among these, the annual amount of carbon captured by the tree cover has been estimated as 13,490 tons, and the total amount of carbon stored by the crown cover has been estimated as 338,840 tons (Table 2).

Table 2: I-tree canopy estimates and analysis results of benefits from crown canopy in the area

\begin{tabular}{|l|l|l|l|l|}
\hline $\begin{array}{l}\text { Pollutants removed } \\
\text { from the } \\
\text { atmosphere }\end{array}$ & Amount & \pm GD & Value (USD) & \pm GD \\
\hline $\begin{array}{l}\text { Carbon Monoxide } \\
\text { removed annually }\end{array}$ & 1.22 tons & 0.05 & 114 & 5 \\
\hline $\begin{array}{l}\text { Nitrogen Dioxide } \\
\text { removed annually- }\end{array}$ & 6.63 tons & 0.28 & 196 & 8 \\
\hline
\end{tabular}

\begin{tabular}{|c|c|c|c|c|}
\hline $\mathrm{NO}_{2}$ & & & & \\
\hline $\begin{array}{l}\text { Ozone removed } \\
\text { annually }-\mathrm{O}_{3}\end{array}$ & 66 tons & 2.76 & 10.220 & 427 \\
\hline $\begin{array}{l}\text { Particulate Matter } \\
\text { less than } 2.5 \\
\text { microns removed } \\
\text { annually - PM2.5 }\end{array}$ & 3.21 tons & 0.13 & 21,126 & 883 \\
\hline $\begin{array}{l}\text { Sulfur Dioxide } \\
\text { removed annually- } \\
\mathrm{SO}_{2}\end{array}$ & 4.18 tons & 0.17 & 34 & 1 \\
\hline $\begin{array}{l}\text { Particulate Matter } \\
\text { greater than } 2.5 \\
\text { microns and less } \\
\text { than } 10 \text { microns } \\
\text { removed } \\
\text { annually - PM10-2.5 }\end{array}$ & 22.11 & 0.92 & 7.419 & 310 \\
\hline $\begin{array}{l}\text { Carbon dioxide } \\
\text { captured by woody } \\
\text { plants - } \mathrm{CO}_{2} \text { seq } \\
\text { (annual) }\end{array}$ & $\begin{array}{l}13.490 \\
\text { tons }\end{array}$ & 0.56 & 691.787 & 28,904 \\
\hline $\begin{array}{l}\text { Carbon dioxide } \\
\text { stored by woody } \\
\text { plants - } \mathrm{CO}_{2} \text { stor }\end{array}$ & \begin{tabular}{|l|}
338.840 \\
tons
\end{tabular} & 14.16 & 17.373 .373 & 725,880 \\
\hline
\end{tabular}

Classification of the sizes and densities of urban environmental components is important in terms of understanding the ecosystem dynamics in these areas and the services they provide. In this study, the annual economic value of the regulating ecosystem services provided by tree covering $16.03 \%$ of the selected sample area and aimed at improving the air quality was calculated as approximately 17 million USD (Fig. 4).

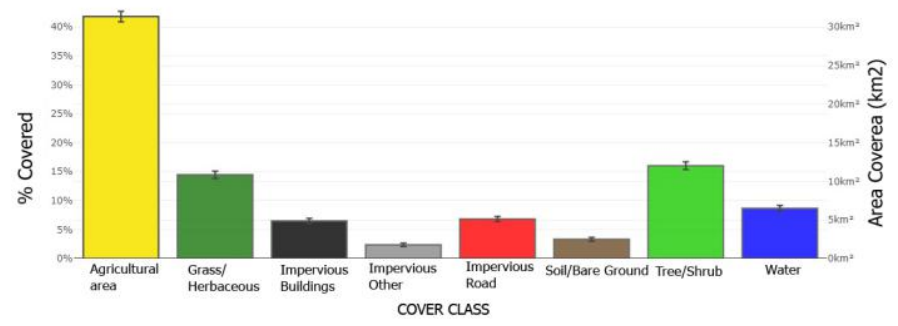

Fig. 4: Graphic of land cover and cover classes of the area

Some plant species commonly seen in open-green areas of Wageningen city are [13]; Abies alba, Abies grandis, Acer campestre, Acer platanoides, Acer pseudoplatanus, Aesculus hippocastanum, Alnus glutinosa, Alnus incana, Betula pendula, Betula pubescens, Carpinus betulus, Castanea sativa, Chamaecyparis lawsoniana, Corylus avellana, Crataegus laevigata, Crataegus monogyna, 
Fagus sylvatica, Fraxinus excelsior, Ilex aquifolium, Juniperus communis, Larix decidua, Larix kaempferi, Malus sylvestris, Mespilus germanica, Picea abies, Picea omorika, Picea orientalis, Pinus mugo, Pinus nigra, Pinus pinaster, Pinus strobus, Populus alba, Populusxcanadensis, Populus nigra, Populus tremula, Prunus avium, Prunus padus, Pseudotsuga menziesii, Prunus spinosa, Pyrus communis, Quercus petraea, Quercus robur, Quercus rubra, Salix alba, Sambucus nigra, Tilia cordata, Tilia x vulgaris, Ulmus glabra, Ulmus $x$ hollandica, Ulmus minor. With i-Tree tool, species distinction is not made by considering the tree cover of all trees and tall shrubs. With this method, statistical estimations are made regarding the air quality of the area and the economic value it provides [14]. This situation creates contradictions regarding ecosystem services and economic returns, but even if it is considered as a deficiency in determining real values, i-Tree and similar applications are very important in making planning decisions by making simple, short time and low-cost evaluations for large-scale studies applied in large areas.

\section{CONCLUSION}

In recent years, ecosystem services provided by open and green spaces in urban areas have come to the forefront with their ecological and economic benefits in many studies. It is known that carbon dioxide and carbon monoxide gases are among the greenhouse gases that have the highest share in global warming. Forest areas have climate protection functions by protecting settlements, agricultural areas and recreational facilities from the harmful effects of cold weather and wind, extreme weather changes and improving the regional climate [15]. Among the studies on forests, especially in the determination of regulating ecosystem services, data such as age, height, distribution of vegetation are discussed. In this respect, it is very important to consider each plant species separately. In this sense, although I-tree canopy applications are criticized for not making a very detailed examination, it is an application that makes quick, easy and low-cost evaluations in large areas. In addition, this practice is criticized because it calculates data such as climate and vegetation according to the United States and brings a statistical standard [16,17]. However, it is stated that good results are obtained with the I-tree canopy application in many countries around the world. Countries such as Australia, Canada, England, the Netherlands, Switzerland can be given as examples to these countries [18].

The sensitivity increases as the number of points selected in the I-tree canopy application increases. To give an example from similar studies, a total of 1000 points were defined in Florida, Atlantic Beach city study in which the tree cover was analyzed in the $33.6 \mathrm{~km}^{2}$ [19].

Within the scope of this research, it has been determined that open and green areas, which constitute an important part of the research area, make significant contributions to improving the climate, air quality and therefore the economy of the city. It has been determined that the existing tree cover, which covering $16.03 \%$ of the total research area with 3000 points defined in the area removes a total of 103.34 tons of pollutant gases and particles from the air annually. The regulating impact of the ecosystem service is estimated to contribute to the economy at 17 million USD annually. [20] calculated in their study that Ege University Lodgings Campus made important contributions to improve the air quality and the wide and dense tree cover in the campus removed a total of 324.47 tons of harmful pollutants annually from the atmosphere and stored 8.107,86 tons of $\mathrm{CO}_{2}$ throughout their lifetime, which is very important contribution to the city. [18], in their study conducted in 6 central districts of Aydın province, Efeler district, determined that the existing tree cover, which covers only $14.22 \%$ of the study area, removes a total of $2,851.98 \mathrm{~kg}$ of pollutants per year from the atmosphere and provides an estimated economic contribution of 3,741,791 Turkish Lira.

It is an undeniable fact that vegetation, especially in cities and regions close to cities, contributes to the regional economy by removing pollutants from the atmosphere, increasing the air quality, and increasing the amount and quality of green areas with each unit.

Forest ecosystems provide terrestrial carbon sinks by providing natural carbon retention with the amount of carbon they store in soil and plant (biomass structure). Accurate estimates of forest biomass carbon sinks can improve our understanding of carbon cycles and help in developing sustainable landscape planning and management policies in the face of climate change [15]. In this sense, it is extremely important to increase the similar studies that constitute the regulating services of ecosystem services and to integrate them into planning studies around the world.

\section{REFERENCES}

[1] Westman, W.E. (1977). How much are nature's services worth? Science 197: 960-964.

[2] MEA. (2005). Ecosystems and Human Well-Being Biodiversity Synthesis, Millennium Ecosystem Assessment, Island Press, Washington DC.

[3] Anonymous. (2005). Ecosystems and human well-being: Synthesis. Millennium Ecosystem Assessment, Island Press, Washington, 155, DC. 
[4] Albayrak, İ. (2012). Ekosistem Servislerine Dayalı Havza Yönetim Modelinin İstanbul Ömerli Havzası Örneğinde Uygulanabilirliği. Doktora Tezi. İstanbul Teknik Üniversitesi, Fen Bilimleri Enstitüsü, İstanbul, $198 \mathrm{~s}$.

[5] Berne, R.M., Levy, M.N., Koeppen, B., Stanton, B.A. (1998), Physiology. Fourth edition. St. Louis, Missouri: Mosby Publishers; p. 519.

[6] Scott, C.E., Bliss, T., Spracklen, D.V., Pringle, K.J., Dallimer, M., Butt, E.W., Forster, P.M. (2016). Exploring the Value of Urban Trees and Green Spaces in Leeds UK. [Gorse, C. And Dastbaz, M. (der.)] Proceedings of Int. SEEDS Conference 2016, Int. SEEDS Conference: Sustainable Ecological Engineering Design for Society, 14-15 September, Leeds Beclet University, UK.

[7] American Lung Association, State of the Air. (2005). Available at Retrieved from http:// lungaction.org/reports/sota05_heffects3a.html. (Access:05.01.2022).

[8] Forman, R.T.T. (2008). Urban regions: ecology and planning beyond the city, NY Cambridge University Press, p. 408. ISBN-13: 978- 0521670760.

[9] Ahern, J., Cilliers, S. \& Niemela, J. (2014). The concept of ecosystem services in adaptive urban planning and design: a framework for supporting innovation, Landscape and Urban $\begin{array}{llll}\text { Planning, } & \text { 125: } & 259 & \end{array}$ http://dx.doi.org/10.1016/j.landurbplan.2014.01.020

[10] Anonymous. (2011). i-Tree Canopy Technical Notes. Retrieved from https://canopy.itreetools.org/resources/iTree_Canopy_Metho dology.pdf. (Access: 08.02.2020)

[11] Wikipedia. (2022). Nederrijn. , Retrieved from https://en.wikipedia.org/wiki/Nederrijn.(Access:05.01.2022)

[12] USDA. (2022) United States Department of Agriculture Forest Service, i-Tree Tools, i-Tree Canopy, Retrieved from: https://canopy.itreetools.org/ (Access: 18/01/2022).

[13] WUR, (2022). Temperate Species - Tree Database, Retrieved from https://www.wur.nl/en/ResearchResults/Chair-groups/Environmental-Sciences/ForestEcology-and-Forest-Management-Group/Education/Treedatabase/Temperate-Species.htm. (Access: 17/01/2022).

[14] Hilde, T. \& Paterson, R. (2014). Integrating Ecosystem Services Analysis into Scenario Planning Practice: Accounting for Street Tree Benefits with i-Tree Valuation in Central Texas. Journal of Environmental Management 146: 524-534.

[15] Ersoy Mirici \& M., Tülek, B.(2020). Spatial Distribution of Gokcay Basin Forest Biomass and Carbon Storage Service, Oxidation Communications, Vol. 43 (3):503-515, ISSN 0209-4541.

[16] Tuğluer, M. \& Gül, A. (2018) Kent Ağaçlarının Çevresel Etkileri ve Değerinin Belirlenmesinde UFO E Modelinin Kullanımı ve Isparta Örneğinde İrdelenmesi. Turkish Journal of Forestry 19(3): 293- 307.

[17] Çakmak, M.H. \& Can, M. (2020) Mamak İlçesinin (Ankara) Hava Kalitesinin İyileştirilmesine Yönelik Düzenleyici
Ekosistem Hizmetlerinin Hesaplanması. Bilge International Journal of Science and Technology Research 4(2): 141-149

[18] Ersoy Tonyalığlu, E., Kesgin Atak, B., Yiğit, M. (2021). Düzenleyici Ekosistem Hizmetlerinden Hava Kalitesinin Efeler -Aydın Örneğinde İncelenmesi, ADÜ Ziraat Dergisi, 2021;18(1):119-125, doi: 10.25308/aduziraat.867541.

[19] Marcus, C. (2015). Tree canopy assessment city of Atlantic Beach Florida, Legacy Arborist Services Tallahassee, FL, p. 8.

[20] Coşkun Hepcan, Ç. \& Hepcan, Ş. (2017). Ege Üniversitesi Lojmanlar Yerleşkesinin Hava Kalitesinin İyileştirilmesine Yönelik Düzenleyici Ekosistem Servislerinin Hesaplanmas1. Ege Üniversitesi Ziraat Fakültesi Dergisi, 54(1): 113-120. 